\title{
Vaimud, tulnukad ja Slenderman: üleloomulikud kogemused tänapäeva ópilaspärimuses
}

\author{
Reet Hiiemäe \\ Eesti Kirjandusmuuseumi folkloristika osakonna vanemteadur \\ reet@folklore.ee
}

\begin{abstract}
Teesid: Artikkel keskendub järjepidevuse ja muutuste kaardistamisele õpilaste üleloomulikke kogemusi käsitlevas pärimuses: tuuakse välja levinumad tegelaskujud, üleloomulike uskumustega seotud hirmud ja emotsioonid ning nende tasakaalustamiseks kasutatavad üleloomulikul alusel põhinevad kaitsemehhanismid. Üks artikli fookusteemasid on kultuurilised ja keelelised laenud (nt rahvusvahelise levikuga uustulnukad nagu Slenderman) ning nende allikad (nt filmid, arvutimängud, narratiivne folkloor). Juttu tuleb ka õpilaste memoraatides avalduva fantaasia ja tegeliku elu juhtumite, uskumise ja mitteuskumise vahekordadest. Artikkel põhineb alates 1992. aastast õpilastelt kogutud materjalidel, kuid paralleele tõmmatakse ka traditsioonilise vanema pärimusega.
\end{abstract}

Märksõnad: hirmud, laste folkloor, rahvausund, tänapäeva folkloor, uskumusolendid

\section{Sissejuhatus ${ }^{1}$}

Viimastel kümnenditel on folkloristid traditsioonilise arhiivipärimuse kõrval järjest enam uurinud olevikunähtusi, näiteks hiljuti formeerunud ja elavas käibes uskumusi ja nende dünaamikaid. Laste ja noorte üleloomulike uskumuste ja kogemuste kohta pole aga ilmunud kuigi palju uurimusi (nt Kõiva 1995). Eesti ajalooliste rahvaluule suurkogumiste ajal 19. sajandi lõpus ja 20. sajandi esimesel poolel pöörati laste usundilisele pärimusele vähe tähelepanu ja ka nüüdisuurimustes on olnud rõhk pigem teistel aspektidel. Samas on nüüdseks kogunenud rohkelt värvikat ja mitmekülgset temaatilist materjali, mis väärib põhjalikumat käsitlemist. Käesoleva artikli fookuses on tänapäeva õpilaste üleloomulikud kogemused, eelkõige kokkupuudetest uskumusolenditega rääkivad isikukogemuslood (memoraadid või sekundaarsed memoraadid), nendes ilmnevad muutused ja järjepidevad jooned. Mare Kõiva eeldas juba oma 1995. aasta lastepärimuse artiklis, et laste isikuelamustel peaks moodsas ühiskonnas olema oma nišš, kuna üleloomulikke elamusi ja nende suulisi realisatsioone 
aktsepteerib osa tänapäevaseid pärimusekandjaid ning soosib massimeedia. Näib, et hilisemates koolipärimuse korjandustes on üleloomuliku kallakuga isikukogemuslugude roll üha suurenenud.

Seoses nutiseadmete ja interneti laialdase ligipääsetavusega on lapsed ja noored globaalse massikultuuri nähtuste mõjuväljas (nt Youtube’i vaimuvideod jm üleloomulikkusega haakuv sisu, Harry Potteri raamatud ja filmid jm sarnased meediatooted, populaarsed esoteerikavoolud), mis loob tugiraamistiku teadlikkuseks vastavatest karakteritest ja süžeeliinidest, samuti eeldused nende ülevõtmiseks ja adapteerimiseks (vrd Garvis 2015: 1). Sellega seoses on üleloomulikud uskumused käesoleval sajandil tuntavalt mitmekesistunud perepärimusena edasikantavatele kujutelmadele on lisandunud eklektiline kombinatsioon paralleele teistest kultuuridest, mida ammutatakse meediast või interaktsioonist eakaaslastega. Seega on käesoleva uurimuse üks eesmärk õpilaste üleloomulike kogemustega seotud pärimuse hetkeseisu kaardistamine, olulisemate joonte ja eeskujude väljatoomine ning analüüsimine.

Uurimuse aluseks on kolme koolipärimuse kogumisaktsiooni (1992, 2007 ja 2017-2018) käigus laekunud õpilaste omakäelised kirjeldused, millest kõige põhjalikumalt töötasin läbi viimase aktsiooni teemakohased tekstid, samuti olid toeks mõned 2017. aastal 9-14aastaste õpilastega tehtud fookusgrupi intervjuud ja vähesel määral täiskasvanute lapsepõlvemälestused. Kolme koolipärimuse kogumisaktsiooni käigus laekunud üleloomulike kogemuste kirjelduste hulk ulatub sadadesse, nende esitajate vanus jääb valdavalt vahemikku 10-18 eluaastat (ehk siis 4.-12. klassini).

\section{Usundiliste kujutelmade ealisest aspektist}

Erinevate earühmade materjali kõrvutamine võimaldab teha järeldusi usundiliste kujutelmade ja nendega seotud isikukogemuste muutumise kohta seoses kogeja vanusega. Mikhail Lurie räägib õpilashuumori kontekstis "parim enne kuupäevast" ehk siis teatavate vanuserühmade hulgas populaarsetest naljadest, mis laste vanemaks saades kaotavad aktuaalsuse ja atraktiivsuse. Sama kehtib ka usundiliste kujutelmade (näiteks teatavate hirmutusolendite) kohta, millesse uskumisest sageli hilisemas eas loobutakse (vrd sarnane tähelepanek Kõiva 1995: 322). Paljudes vastusetekstides kirjeldavad vanemate klasside õpilased oma varasemaid hirmuuskumusi ja nendest järkjärgulist väljakasvamist. Merle Taimalu uurimus laste hirmudest (2010) pakub samuti teavet kujutelmade vanuselise mõõtme kohta: hirmu kummituste ja koletiste (monstrumite) ees esines tema uurimuse põhjal 75 protsendil lasteaialastest, 50 protsendil 2 . klassi lastest ja vaid 5 protsendil 6 . klassi lastest. Koolipärimuse 
aktsioonide pärimusmaterjali põhjal tundub selle hirmu esinemus vanemate klasside õpilastel isegi suurem, kuid teatud olenditesse uskumine ja sellega seonduv hirm võivad avalduda mitte pidevalt, vaid situatiivselt, näiteks pimedas ruumis või pärast õudusfilmide vaatamist.

Ent ka hirmuuskumused, millest ollakse välja kasvanud, võivad sellegipoolest pakkuda aruteluainest või suhestumisplatvormi, näiteks kommenteeris üks 12aastane poiss tänaval valget kaubikut parkimas nähes oma 9aastasele sõbrale naerdes: "Ahhaa, see on see valge mikrobuss, millega lapsi röövitakse" (2016). Kommentaar näitab teadlikkust aktuaalsetest valge kaubikuga seoses rahvusvaheliselt käibivatest usundilistest motiividest ning et lasterööviga seotud pärimuse referentstähendust kandev objekt oli rääkijate seas teadvustatud, kuid ühtlasi ka soovi väljendada nendest üleolekut (vrd Hiiemäe 2016a: 55). Õpilaste kokkupuuted heterogeensete rühmadega - sõbrad, pere, kool, treeningukaaslased - ja nendes rühmades tekkivad jutustamisvõimalused on üks mooduseid pärimusmotiivide transmissiooniks ja eluspüsimiseks.

Üheks üleloomulike hirmude oluliseks allikaks on jätkuvalt olendid, kellega lapsevanemad hirmutavad lapsi, et neid kuulekusele sundida (nt vältida laste minekut keelatud kohtadesse või neid õigel ajal magama saada). Kuigi lastehirmutiste grotesksus on aja jooksul vähenenud ja osa tegelasi on asendunud uutega, on nii 1992., 2007. kui 2017.-2018. aasta materjalis lastehirmutiste kohta rohkelt teateid; lisaks klassikalistele kotionule, kollile ja koletisele kohtab nimelist individuaalloomingut, nagu Kaevu-Ella, Mekelmüts. Huvitav transformatsioon on täheldatav ühes 2007. aasta tekstis, milles traditsiooniline hirmuolend kotionu on asendunud ufoga:

Mind on küll täiskasvanud hirmutanud: ufo tuleb viib mu minema, kui ma hea laps ei ole. See oli aastaid tagasi minuga (KP 2007 < Väike-Maarja $<$ tüdruk, 5. kl, 2007).

On ka mõnevõrra ootuspärane, et iganenud tegelaskujud asendatakse millegi antud kultuurikontekstis ja perioodis arusaadavama ja intrigeerivamaga ning ehk ka lapsele enam resonantsi pakkuvaga. Olgugi et hilisemas eas hirm lastehirmutiste ees enamasti taandub, olid neid ja nendega seonduvaid emotsioone retrospektiivis kirjeldavad tekstid jätkuvalt värvikad ning mälestused kogetud hirmust elavad.

Üldise kontekstina on vaja kogemusjuttude sõnastus- ja esitusviiside analüüsil arvesse võtta ka lapse staatuse muutumist ühiskonnas viimastel kümnenditel. Laste õiguste rõhutamine ja laste kohtlemine üha võrdväärsemal tasandil täiskasvanutega on kaasa aidanud laste kontrolli- ja võimutunnetuse tugevnemisele ning ka isikukogemuslugudes võib täheldada pigem jutustaja esinemist aktiivse sekkuja ja olukorra kontrollija, mitte passiivse vaatleja või 
ohvrina. Näiteks järgmises näitetekstis kirjeldab üks tüdruk, kuidas ta hirmutajad läbi nägi, mistõttu nende hirmumeetod ei andnud oodatud efekti:

Mind hirmutasid vanemad ühe koletisega, kes pidi nutvad lapsed ära sööma, kuna ma olin väiksena päris jonnakas laps. Aga ma olen aru saanud, et sellist koletist pole olemas ja et ma võin rahulikult nutta, ilma et keegi mind ära sööks (ID3412, tüdruk, snd 2004, Rõuge, 2018).

Teisalt osutab erinevas vanuses laste narratiivide struktuuri uurinud Brian Sutton-Smith (1981) Elli Köngäs-Maranda ja Pierre Maranda 1970. aastal esitatud neljaastmelist mudelit kasutades, et vanuse kasvades hakkavad lapsed end oma narratiivides rohkem kirjeldama otsustaja ja probleemide lahendaja positsioonilt, näiteks kümneaastased jutustajad teevad seda olulisemalt sagedamini kui viieaastased (Sutton-Smith 1981: 20-24). Eesti koolipärimuse korjandustes osalenud õpilaste ea alampiir jääb enamasti 4. klassi (umbes kümnenda eluaasta) juurde. Samas on kirjelduste puhul siiski täheldatav teatav juhtumipõhisus - väga traumeeriva ja hirmutavana kirjeldatud olukordade puhul võivad ka vanemad õpilased end vahel kirjeldada abitu ohvri rollis.

\section{Rühmapärimuse ja rühmakogemuste vastastikmõjud}

Koolipärimuses tuleb tihti esile rühmadimensioon - palju tegutsetakse sõpradega koos ja ka üleloomulikeks liigitatud kogemustel on nii mõnelgi korral rohkem kui üks tunnistaja. Eriti kehtib see õpilaste tahtliku rühmaviisilise põnevuse otsimise juhtudel, milleks võivad olla kas ühine vaimude väljakutsumine, öises surnuaias käimine või mahajäetud majades uitamine, kuna nimetatud tegevusi sooritatakse vaid väga harvadel juhtudel üksinda. Enamasti on need juba ette laetud negatiivsete ja ohtlike üleloomulikkusega seotud konnotatsioonidega, mistõttu ollakse altid kogetut tõlgendama üleloomulikus võtmes või mõnikord tegevust juba ennetavalt katkestama, kuna kardetakse, et selle üleloomulik osa või isiklikud hirmuaistingud võivad kontrolli alt väljuda, nagu kirjeldatakse ka järgmises tekstis:

Valge daam on õuduste kuninganna. Kui olla küünlavalgel, seista peegli ees ja öelda nõiasõnad, siis hakkab kõik helendama ning peeglist võib näha, et su seljataga on naine valgetes rõivastes ja õuduste kuninganna ise on poole kehaga. Kui hakkad naerma, sirutab valge daam oma käed sinu kõrile ja kägistab su ära. Oleme proovinud, aga alati põgenen ma enne ära, ei julge. Tean, et see on kõik vale, kuid ikkagi kardan (EKRK I 97, 271 (15) < Tartu, tüdruk, 12 a, 1992). 
Tahtlik kontaktivõtt vaimumaailmaga või teadlik liikumine kohtades, kus nende kohalviibimist peetakse ootuspäraseks, võib luua võimsa psühholoogilise elamuse, aga ka neurootilise hirmukogemuse, ehk nagu märgib Mare Kõiva (1995: 310): "Mängust eluks ajaks mällusööbiva hirmuelamuseni on väike vahemaa, sealt edasi situatiivse jutuni, mida olukorrale kohandatakse, on tee veel lühem." Öeldu kehtib näiteks meelelahutusena läbiviidud vaimu väljakutsumise rituaalide puhul, mille kirjeldustest selgus korduvalt, et kuigi rituaali eesmärk oligi vaimu välja kutsumine, oli vaimu tegelik ilmumine siiski ootamatu ja hirmutav, paisates segi senised kujutelmad reaalsusest, kusjuures kaaslaste reaktsioonide jälgimine suurendab jutustaja ehmatust pigem veelgi.

Rühmakogemuseks võib anda alust ka mittetaotluslik spontaanne kogemus - näiteks koolikummituse ilmumine, kui on olemas eelteadmine kummitamise võimalikkusest ning teatavaid märke (nt uste iseeneslik avanemine või sulgumine, kriuksatused, sammud) tõlgendatakse selle kinnitusena. Samuti oli ühes kirjelduses surnuaias kohatud tundmatu mehe puhul esimene assotsiatsioon, et tegemist on üles ärganud surnuga (ID2333, poiss, snd 2001, Jõhvi, 2018). Seega võib mingi üksik akustiline detail või muu mitteverbaalne signaal saada terve jutu süžee ja sellega seonduva tõlgenduste seeria aluseks (vrd Hiiemäe 2016b: 40). Öelduga haakub narratiivipsühholoogiat uurinud Daniel Hutto märkus: "Narratiivid toimivad normaliseerivate seletustena ja võimaldavad toime tulla ebatavaliste või ekstsentriliste olukordadega, asetades need - kui võimalik - konteksti, milles need muutuvad mõistetavaks" (Hutto 2008: 7).

Nii võib näiteks ühe piirkonna koosmängivate laste või ühes koolis käivate laste seas üleskerkiv üleloomulik tõlgendus vallandada terve rea järgmisi kogemusjuhtumeid, mida interpreteeritakse samal viisil. Sageli seostuvad sellised sarinarratiivid mingis kindlas kohas kogetud kummitusfenomenidega, aga ka mitte nii üheselt üleloomulike tunnustega juhtumitega, näiteks ühe Tartumaa asula laste meeli köitis kuude kaupa pidevalt helendava ekraaniga seadet kasutav tume kogu pargis. On iseloomulik, et nagu muugi elu, võivad ka tänapäeva üleloomulikud olendid olla kujutatud tehnologiseerituna, ent see omadus võib sujuvalt ühte sulada ülivõimete ja üleloomulikkuse kirjeldamisega ning sellega seotud ähvardavusega. Näiteks iseloomustatakse järgmises tekstis juba eespool mainitud tumedat kogu mitte lihtsalt seisvana, vaid varitsevana:

9aastane poiss: Talvel oli küll tume kogu, kes seisis ja varitses pargis ja vaatas kogu aeg telefoni helendavat ekraani. [---] Kusjuures ta on ainult pimedal alal-õues pargis ja prügikonteinerite juures - ja ta on seal ainult sügisel, talvel ja kevadel.

Intervjueerija: Aga kas kuidagi ennast tema vastu kaitsta saab?

11aastane poiss: Lihtsalt ei lähe sinna. 
9aastane poiss: Kui mul oleks pussnuga ja püstol ja sõbrad kaasas, siis ma julgeks minna küll (intervjuu kahe poisiga, Tartumaa, 2016).

Kirjeldatud hirmuolend ise paigutus kuhugi inimliku ja üleloomuliku piirialale, näiteks küsimusele, kas pargis nähtud olend on pigem inimene või mitte, vastas 11aastane poiss:

Ma ei tea, aga pigem on ta inimene. Aga ta on küürakas, üleinimsuurune ja tal on vahepeal palk käes - nagu pesapallikurikas, aga palgisuurune. [---] Ta on umbes nagu Slenderman, aga ta ise pole Slenderman (intervjuu kahe poisiga, Tartumaa, 2016).

Võrdlus Slendermaniga - eelkõige just lapsi jälitava, rööviva ja traumeerivana kujutatud rahvusvaheliselt tuntud hirmuolendiga - osutab, et esimesena meenus jutustajale võrdluses nimelt tänapäevane meediamõjuline n-ö moeolend, mitte mõni vana traditsioonilise pärimuse vaimolend. Kirjeldatud olendi puhul on aga inimkuju kombineeritud hiiulike omadustega (üleinimsuurune kogu kandmas palgisuurust kurikat), lisaks on aimatavad muud meediamõjud, näiteks viide pesapallikurikale, millest on saanud meedias seoses viimasel kümnendil toimunud raskete õigusrikkumistega üks vägivallakuritegude koondmetafoore. Muuhulgas joonistub eelkirjeldatud olendiga seoses välja teatav kohasidusus, n-ö mentaalne ohukaart: tema liikumine on konkreetselt piiritletud pimedate aladega ja lisaks ka ajalise raamiga - oht püsib ainult sügisest kevadeni. Samuti kirjeldatakse kahte võimalikku subjektiivset turvatunnet tagavat käitumisalternatiivi: vältimist ja kujutlusvõime tasandil agressiooni. Antud juhtum küll kaotas lõpuks oma üleloomuliku mõõtme ja sellega seonduva hirmutava kvaliteedi ning ühes sellega kadusid ka vastavad jutud kiiresti käibelt, kuna selgus, et pargis käis õhtuti üks kohalik noormees oma sõbrannaga kohtumas ja ekraani helendamine oli tingitud kohtumise kokkuleppimiseks mobiilisõnumite vahetamisest.

Mis puudutab tänapäeva tehniliste võimaluste kajastumist üleloomulikke kogemusi käsitlevates lugudes, siis 2018. aasta materjalis leiduvate kirjelduste põhjal võib üleloomulike olendite kogemine saada võimalikuks just moodsa tehnika kaasabil, näiteks mainitakse vaimude väljakutsumiseks kasutatavat mobiiltelefoni äppi, Youtube'ist vaadatavaid videoid, mille põhjal õpilased vaimudega suhtlemist õpivad, vaimolendite ülesvõtmist telefonikaamera fotodele või videosse või vastupidi, videopildi häirumist, mida tõlgendatakse kui teispoolse olendi kohalolekust tingitut.

Vahel püütakse välja kutsuda ka muidu positiivse konnotatsiooniga tegelasi, kuid olukorra liminaalsuse tajumine seob ka nemad ohutundega. Suhteliselt väheesinev, kuid narratiivselt mõjus on järgnevas näitetekstis esinev hea olendi ootamatu demoniseerumine. Ka tänapäeva muinasjutufilmides kujutatakse 
sageli heaks maskeeritud pahasid tegelasi ja nende paljastamist, aga selline skript ei ole pärimuse tasandil eriti kasutust leidnud:

Me kutsusime tüdrukutega päkapikku välja. Me panime vett kausi sisse ja maasika, siis ootasime ja väike päkapikk tuligi. Aga järsku see päkapikk hakkas kasvama ja koledaks minema. Me tõime ruttu taskulambi ja panime põlema. Päkapikk kadus ära ja ka maasikas kadus ära (RKM, KP 1, 128 (15) < Narva, tüdruk, 4. kl, 1992)

Paaril juhul lisandus üleloomulikule kogemusele seksuaalsuse aspekt ehk veel teine mitte-eakohase temaatikaga ja sellega seonduva liminaalsusega seotud valdkond. Järgnevas tekstis, mille sisuks on pornopäkapiku väljakutsumine, väljendub ühtaegu nii tegutsejate huumoritaju kui ka toimunu seletamatus.

Ükskord läksime koos ema, õe ja vanaemaga surnuaeda, me koristasime hauaplatse. Ühel hetkel ma vaatasin natuke eemale puu juurde ja nägin seal sedasama sugulast, kelle hauda me parasjagu koristasime. Ma hakkasin nutma, aga ma teadsin, et ma kujutan ette, sest ma kujutan igasugu asju endale ette. Ja mu õde kutsus ükskord koos oma sõpradega vaime välja. Nad otsustasid, et võiks kutsuda pornopäkapiku vaimu, seda nad tegid. Ja me ei tea kuidas, aga lõpus tõmmati ühel püksid alla, aga keegi ei puutunud neid pükse (ID2912, tüdruk, snd 2003, 2018).

Surnuaedade ja mahajäetud majadega seotud eelhoiakud ja usundiline etteantus võimaldavad puänteeritud, tihtilugu humoristlikult lõppevaid lugusid, mille käigus grupiviisiliselt kogetud ja algselt üleloomulikuks ohuks peetud nähtus saab reaalpõhjusel põhineva seletuse, milleks on näiteks loodushelid, inimeste tekitatud müra, mõne grupiliikme tahtlik hirmutamispüüe. Järgneva näiteteksti puhul on sündmuskohaks vana (küll mitte mahajäetud) maja:

Kui minu ema oli väike laps, ööbis ta ükskord koos emaga ühes vanas majas Hiiumaal maja teisel korrusel. Oli pime ja tuul puhus kõvasti. Äkki kuulis ta samme ja raksuvat heli, mis pidevalt lähenes, kuni oli tunda, et keegi istus voodi peale ja mälumise moodi raksumine jätkus. Emaema pani äkki tule põlema ja selgus, et see oli tuttav, kes oli kuutõbine ja ööbis alakorrusel, oli ajanud toad sassi ja sõi värsket kurki (ID470, poiss, snd 2006, Pärnu).

Materjalist jäi mulje, et konkureerivate (sh skeptiliste) seletusvõimaluste paljusus tänapäeva pärimuses on tinginud muuhulgas ka selliste naljaks pööratud lugude osakaalu kasvamise. Järgmisest, juba 1992. aastal kirjapandud jutust ilmneb samuti, et mitmekesise usundilise pärimuse ja kultuurilaenude mõjuväljas olemine võib tingida mitme paralleelse seletusversiooni olemasolu, mis 
jutu käigus toodud argumentatsiooni tulemusena taandub enamasti siiski ühele antud hetkel rahuldavale seletusele. Näitetekstis tõusevad esile kolme lapse kolm erinevat üleloomulikku tõlgendust, kui püütakse leida seletust kuuldud müra ja sammude põhjusele, kuni jõutakse täiskasvanu pakutud reaalpõhjuseni, mis näib rahuldavat kõiki osapooli - igatahes lõpeb jututekst tuulest tingitult vastu katust kraapinud okste kindlas kõneviisis kirjeldamisega:

Suvel tegime neljakesi heinalakka põhupallidest onni ning otsustasime, et jääme üheks ööks sinna magama. Ö̈sel ärkasime üles, sest oli külm. Kui me natuke juttu olime ajanud, siis kuulsime katusel mingit müdinat, justnagu oleks keegi edasi-tagasi jooksnud. Kuna hirmul on suured silmad, siis mõtlesime kõige jubedamaid asju. Arvasin, et need on UFO-d. Sõbratar, kellega olin, arvas, et vaimud, mu õde mõtles, et kodukäijad. Me kartsime ja ei julgenud midagi teha. Aga mõne aja pärast müdin lakkas ning me jäime uuesti magama. Hommikul arutasime seda asja, kuid selgusele ei jõudnudki.

Meie maja nurgas kasvab üks suur kuusk, mille oksad ulatuvad katusele. Kui ma emale öisest juhtumist rääkisin, siis ütles tema, et kuuseoksad olidki need müdina tekitajad. Kui tuli tuul, siis oksad liikusid ja olid vastu katust (RKM, KP 40, 220/1 (16) < Järvamaa, tüdruk, 8. kl, 1992).

\section{Meediamõju ja laiem kultuslik-spirituaalne miljöö ühiskonnas}

Laste ligipääs täiskasvanute maailmale interneti ja meedia vahendusel on viimastel kümnenditel hüppeliselt suurenenud, täiskasvanu kommenteerija-roll seevastu vähenenud. 2007. ja 2018. aasta koolipärimuse vastustest ilmnes, et ülekaalukas osa lastest vaatab lausa igapäevaselt mitte-eakohaseid õudus- ja põnevussarju ja -filme, tehes seda kas koos perega, sõpradega või üksi. Uurijad on osutanud, et isegi ilmselgelt fiktsionaalsel meediasisul on mõju selle tarbijate vaadetele ning see võib suurendada usku üleloomulikkusesse (vrd Koski 2016: 18). Merle Taimalu doktoritööst laste hirmude kohta (2010) selgus, et laste televisiooniga seotud hirmud ja kujuteldavate olendite hirm olid muutunud 21. sajandi esimese kümnekonna aasta jooksul oluliselt sagedasemaks, kusjuures koolieelikute seas oli olendihirm hirmude skaalal kolmandal kohal (Taimalu 2010: 38). Väga palju kirjeldati ka koolipärimuse vastusankeetides konkreetsete ekraanil nähtud tegelastega seotud hirme, uskumusi ja õudusunenägusid. 
Teisalt on esoteerilised ja paranormaalsed teemad viimase kümnekonna aastaga meedia- ja meelelahutussfääris sujuvalt muutunud järjest nähtavamaks ja kohati kombineerunud sekulaarse peavoolumõtlemisega - sotsiaal- ja kultuuriteadlased on osutanud selles kontekstis lausa nn paranormaalsele pöördele Lääne ühiskonnas (vrd Koski 2016: 18). Õpilaste vastustest selgus, et nii õpilased kui ka nende vanemad jälgivad sageli otseselt paranormaalsete võimete ja üleloomulikkusega seotud teleformaate (nt "Selgeltnägijate tuleproov"). Mare Kõiva märkis juba 1995. aastal, et "paljud õpilased tunnistasid, et loevad huviga igasuguseid ulme- ja hirmujutte, huvituvad "Paradoks B-s" [1991-2005 ilmunud parateaduslik ajakiri] ilmuvatest lugudest ning peavad tõeväärseteks hingede rändamist ja reinkarnatsiooni, poltergeisti ning meediumitesse puutuvat informatsiooni. Küllalt paljud olid koos vanematega külastanud imearste või kaartidega ennustajaid" (1995: 316). Mõned psühholoogia valdkonna uurijad on üleloomulike kogemuste avaldumise seaduspärasusi otsides osutanud tugevale seosele indiviidi üleloomulike uskumuste ja empiiriliste üleloomulike kogemuste vahel (nt Pechey \& Halligan 2012), kuid koolipärimuse materjali põhjal ei olnud küll võimalik selgelt eristada, kus lõpevad personaalsed üleloomulikud uskumused ja algab lihtsalt viibimine ühiskonnas prevaleeriva kultuslik-spirituaalse miljöö mõjuväljas, mis ei ole veel aktualiseerunud personaalsete uskumuste või kogemustena. Antropoloog Kirsten Maria Raahauge märgib täiskasvanute vaimupärimuse kontekstis, et enamik tema intervjueerituid, kes enda sõnul ei uskunud vaimudesse, kasutasid iseenda seletamatuid kogemusi kirjeldades sellegipoolest terminit "vaim" või "kummitamine" (Raahauge 2016: 97). Samas sugenevad tänapäevane üleloomulikkusega seotud sõnavara ja rõhuasetused ka klassikalistesse vaimukujutelmadesse ja põimuvad vanemate kujutelmadega, näiteks järgmises tekstis räägib üks õpilane, et vaimudetunnil tõusevad surnud üles "nagu zombid", tuues võrdluse eesti usundis 20. sajandi lõpus uustulnukana juurdunud olendiga:

Mulle väiksena öeldi, et surnuaias, kui kell lööb 00.00 öösel, siis tõusevad surnud inimesed nagu zombid üles ja käivad ringi (KP 2007 < VäikeMaarja < tüdruk, snd 1993, 2007).

Mare Kõiva märgib õpilaste uskumustes avalduvat meediamõju, eriti ekraanimeedia mõju kommenteerides: "Visualiseeritud mütoloogia, mis on tihti adapteeritud ning autoriseeritud, ühtlustab rahvapärimust maal ja linnas" (1995: 321). Samas võis teatavast ühtlustumisest hoolimata täheldada 2018. aasta koolipärimuses rohkelt ka nn klassikalisi lokaalseid kummitusjutte ja nendega seotud kollektiivseid kummituskogemusi (vrd sama tähelepanek 2007. aasta kogumisaktsiooniga seoses Voolaid 2007: 160). Seega on paralleelselt jätkuvalt olemas piirkondliku varasema pärimuse mõju - koolikummituslood, koolideks 
ümberehitatud vanade haiglate ja mõisahoonetega seonduvad müstilise kallakuga süžeed. Vahel seostatakse traditsioonilistele muistenditele omaseid rändmotiive konkreetsete isikutega, näiteks surnud koolidirektoriga, keda usutakse oma kunagisel tööterritooriumil kummitavat. Mõnikord võivad paralleelselt käibel olla reaalpõhjuslikud ja üleloomulikud tõlgendused, näiteks koolis kostvat müra võidakse seletada ventilatsioonitorudes liikuva õhu või ka kummituse tegevusega. Seega põhinevad paljud üleloomulikke kogemusi kirjeldavad jutud tegeliku elu kogemustel, mida verbaliseeritakse olemasoleva folklooritraditsiooni vaimus, järgides väljakujunenud tõlgendamis- ja kirjeldamisviise (vrd sarnane tähelepanek Hufford 1989).

2018. aasta koolipärimuse vastustest tuli välja, et paljude õpilaste vanemad (eelkõige emad, aga ka mõned isad) huvituvad esoteerikast, neil on lastega selleteemalisi arutelusid, mõned lapsevanemad kingivad oma järeltulijatele amulette või soovitavad maagilisi kaitseviise. Seega võib ka lapsevanemate vastuvõtlikkus müstikale ja usundilistele elamustele mõjutada lapsi üleloomulikkuse võimalikkust aktsepteerima. Üleloomuliku ainestiku nähtavalolek nii eravestluses kui ka meedias näitab, et üleloomulik pärimus on üldkultuurilise teadmuse osa, ent kui narratiivi või uskumusena internaliseeritud motiivid ja seletusversioonid avalduvad isiklike reaalelukogemuste tõlgendamise pinnal, ei käsitata neid enam lihtsalt kuuldud teabena, vaid faktilise tõestisündinud juhtumina.

\section{Hea ja halva stereotüübid}

Õpilaste kirjeldustes on tavaline must-valgelt polariseeritud hea ja halva kujutamine nii tavaelu ohtude kirjeldamisel kui ka olendimaailmas ning siin võib täheldada teatavat vanemates muinasjuttudes ja uuemates muinasjutufilmides läbivate skriptide kordumist. Eriti just kogejale kummalisena tunduvates mitteverbaalsetes olukordades võetakse olukordade mõtestamisel appi üleloomulikkuse ja ohuga seotud stereotüübid, kohandades neid teatud määral ajastuomase traditsiooni järgi - näiteks see, mida sada aastat tagasi peeti ehk vaimuks, võib nüüd pälvida tõlgendamist ka näiteks tulnukana. Koos tähendusnüanssidega uueneb meediasidus sõnakasutus: muukeelse meedia kaudu jõuavad õpilasteni uued nimetused - näiteks saavad inglise keele mõjutusel koletistest kohati monsterid ja tulnukatest eilienid. Sealjuures võib mõne tegelaskuju ja nimetuse populaarsus olla väga lühiajaline. Näiteks leidis 2018. aasta materjalis uue nähtusena korduvalt märkimist pikk ja kõhn hägusate näojoontega olend Slenderman (otsetõlkes: slender man - kõhn mees), kellega seotud uskumused said alguse 2009. aastal ühest fotofiktsioonist. Seevastu 1970. aastatel kirjel- 
datud ja Slendermaniga sarnasel moel just lapsi ja noori ohustavaks peetud spetsiifilise välimusega olendit nimega Cropsey (vt pikemalt Haring \& Breslerman 1977) eesti materjalis ei esine, õudusfilmist pärit ja 1990. aastate eesti koolipärimuse materjalis korduvalt mainitud deemonlik surnu Krüger, keda kujutati noorte üle võimust võtvana (vt pikemalt Kõiva 1997), tuli 2018. aasta materjalis jutuks vaid korra.

Olendit, kelle filmi- või muu meedia on täitnud negatiivse sisuga, on raske sellest kuvandist rehabiliteerida. Üks korduvalt mainitud hirmuolendeid 2018. aasta materjalis oli filmimaailma algupäraga tapjakloun, kes omandab kirjeldustes kohati üleloomulikke omadusi. Nii nagu teisegi meediamõjulise uustulnuka - Slendermani - nägemised, lokaliseeritakse tapjaklouni nägemine Eesti õpilaste kirjeldustes koduümbruse tuttavlikku miljöösse ning olgugi et kummagi olendi käitumises ei ilmne väidetavate pealtnägijakirjelduste järgi otseselt agressiivseid jooni, annavad nägijate reaktsioonis tooni hirm ja ettevaatusabinõud. Järgnevas loos on kirjeldus läbinud juba pikema folkloriseerumisprotsessi, kuna refereeritakse tuttavat, kelle sõbranna kodu juures hirmutav vahejuhtum olevat toimunud:

Kunagi ammu - vist 2016 - oli teema killerklounide kohta ja üks mu tuttav on rä̈̈kinud sellest, kuidas ta sõbranna akna alla (ta elab teisel korrusel) seisis vist kirvega inimene ja oli riietunud nagu kloun. See kloun tükk aega vaatas ta koduakent ning ta vanemad olid see aeg tööl (see kõik oli öösel ning ta vanemad olid öövahetuses). Tüdruk kutsus politsei, kuid selleks ajaks oli see inimene läinud (ID1185, tüdruk, snd 2003, Aegviidu, 2018).

Jututegelase identiteedi hägusust kajastab sedastus, et nähtu oli "vist kirvega inimene", kuid tema kavatsusi tajutakse piisavalt ohtlikuna, et kutsuda politsei. Järgneva teksti jutustaja kirjeldab värvikalt oma hirmu Slendermani ees ning ka esialgu seletamatu öine mehekuju viiakse automaatselt seosesse Slendermaniga ("peaaegu nagu Slenderman"). Hiljem suudab jutustaja siiski tuvastada ilmutiseks peetud fenomeni tegeliku olemuse:

Ma kardan tegelikult pimedust, mul on lihtsalt nii hea fantaasia, et suudan ühest varjust mingisuguse vaimu kohe teha. Kõige õudsem olend, keda ma tean, on Slenderman, ta näeb lihtsalt nii oudne välja, vaata seda valget nägu ja tema pikkust, ta sõrmed on eriti pikad! Kohe, kui ma keset ööd tema peale mõtlen, ei saa ma lihtsalt enam magama jääda. Vaimud on ka jubedad, isegi kui ma pole neid kunagi näinud. Mul on siiski juhtunud, et korraga ilmub silme ette mingisugune vaim. Näiteks öösel tahtsin minna vett võtma, aga ma vaatasin aknast välja ja seal oli mingisugune mehe kujutis, nägi välja peaaegu nagu Slenderman. Hiljem ma ei saanud enam magama jääda, aga sellele juhtumile oli ka seletus. 
See “mees” oli minu enda käe vari, mis peegeldus aknast ja see kujutis oli nagu inimese keha pimeduses (ID3218, tüdruk, snd 2002, Lehtse, 2018).

Seega kui ei osata seisukohta võtta, kelle või millega on tegemist, haaratakse esmajoones pärimuslike (kohati meediast kinnitust saanud) stereotüüpide järele. Otsused kohatud isiku seotuse kohta üleloomulikkusega ja sellest tulenevate ohtude kohta tehakse stereotüüpsete väliste tunnuste järgi - järgneva näite puhul annavad isiku mustade riiete, vanuse ja ea kombinatsioon alust liigitada ta nõiaks, ja sellesse valgusesse asetatuna tunduvad jutustajale kahtlustäratavad ka naise pilk ja naer. Sarnaselt klassikalistele muistenditele toimub sündmustik õhtuhämaruses. Kogemuse verbaliseerimise (kirjapaneku) hetkeks on jutustaja juba kohatud isiku identiteedis veendunud, rõhutades tema nõiaks määratlemist pealkirjas hüüumärgiga, teksti lõpus tituleeritakse kohatud naine lisaks veel imelikuks:

Nõid!

Ma olin siis 11-aastane, kui me olime sõbrannaga õues. Õues hakkas juba pimedale kiskuma. [---] Võtsime kelgud ja hakkasime mäe poole sammuma, kui äkki nägime mäe otsas mustas riides vanamoori. Vanamoor vaatas meile otsa ja naeris. Meie jooksime kohe minema. Maja ees seisis [sõbranna] Ave ja rääkisime temale, keda me nägime. Ave tahtis samuti teda näha ja me otsustasime, et läheme mäele tagasi. Kui me sinna jõudsime, siis seda imelikku enam ei olnud. (RKM, KP 90, 272 (2) < Rakvere, tüdruk, 6. kl, 1992)

Üks mõnevõrra ambivalentsemaid hoiakuid esilekutsuvaid nähtusi oli ufod ja tulnukad, kellesse suhtumine ei seostunud tingimata alati hirmuga. Kümnetes koolipärimuse tekstides mainisid õpilased, et ei pea tulnukaid agressiivseks ega ohtlikuks, ja nendega kohtumine tunduks pigem huvitav. Siiski tajuti tegelike tulnukakontaktidena tõlgendatud juhtumeid nende tavavälisuse ja ootamatuse tõttu hirmutavana. Mare Kõiva (1995: 310) sõnul võib laste ufoloori pidada improvisatsioonide ja memoraatide piirialale kuuluvaks. 2018. aasta materjalis oli vastava materjali improvisatoorsus siiski napp, kirjeldati isiklikke kogemusi, mille isiklik läbielatus muutis jutustajate silmis faktiliseks (vrd Partridge 2005: 75-76 isikliku kogemuse pidamisest eksimatult tõeseks ja usaldusväärseks). 


\section{Uskumise, kogemuse, emotsiooni ja nende verbaliseerimise vahekordi}

Koolipärimuse materjalis esinevate üleloomulike kogemuste mõju intensiivsus ei avaldu alati tingimata nende kirjeldustes. On lakoonilisi üleskirjutusi, milles ei selgu kogeja reaktsioon ega emotsioonid, näiteks:

Kui ma olin voodis, siis ma nägin, et minu tuba hakkas valgeks minema, siis ma läksin akna juurde ja nägin seal suurt muna (RKM, KP 1, 128 (15) < Narva, tüdruk, 3. kl, 1992)

Napisõnalisuse põhjuseks võib olla ootamatust kogemusest saadud šokk, oskamatus või soovimatus läbielatut sõnastada, kirjaliku esituse korral ka viitsimatus (mõned õpilased kommenteerisid vabandades, et nad lihtsalt ei viitsi pikalt kirjutada).

Sagedamini kohtab isikukogemuslugudes siiski ülimalt ilmekaid hirmuaistingute ja ehmatusolukordade kirjeldusi. Näiteks järgmises näitetekstis kirjeldab jutustaja, kuidas vanaema rääkis talle oma sõja-aegsest kohtumisest huntidega ning see avaldas talle sügavat mõju - väidetavalt terve öö kestnud ärvel- ja üksioleku käigus tiivustunud kujutlusvõime loob huntidest demoniseeritud pildi, milles signaalmotiivina on esindatud kujutelm verejoomisest. Olgugi et vanaema jutt puudutas juba aastakümneid tagasi toimunud sündmusi, millega lapsel endal puudus otsene kokkupuude, vallandus lapse tugev emotsionaalne reaktsioon jutu kuulmise järgsel hetkel.

Seda juttu rääkis mulle vanaema ühel talvisel õhtupoolikul. Vanaema rääkis nii, et ma ei saanud pärast terve öö enda silmi kinni lasta. Mulle tundus nii, nagu oleksid kõik need hundid minu juures ja kavatseksid nad minust vere ära juua ja minu ära süüa. Mulle räägiti seda, kui ma olin kuue- või seitsmeaastane (RKM, KP 1, 128 (15) < Narva, tüdruk, 4. kl, 1992).

Mõningate üleloomulike kujutelmade puhul võib rääkija või kogeja endale ratsionaalselt teadvustada, et vastavat olendit ei saa olemas olla, kuid olend tekitab tema sellegipoolest hirmu ja sellega seonduvaid muid tugevaid emotsioone. Lisaks mõjub visuaalses meedias (televisioon, kino) nähtu just visuaalsuse tõttu kohalolevalt, sööbib kujutluspildina mällu ja annab toitu fantaasiale. Üleloomulike uskumusolenditega seotud kujutelmad kipuvadki elavnema või visuaalselt manifesteeruma siis, kui laps on üksi, kui on pime või kui laps on juba mingil muul põhjusel ärevil (nt nähtud põnevast telesaatest või filmist, kuuldud vaimujutust). Seega võivad hoiakud ja emotsioonid olla olukorrapõhised - jututegelased, kellest seltskonnas räägitakse naerdes, võivad üksi oma toas und ootavale lapsele meenudes osutuda talumatult hirmutavaks. 
Mõnedki süžeeliinid tunduvad ajas universaalsed. Nagu klassikalistes muistendites, avaldub ka nüüdisaja õpilaste kogemustes süü/eksimuse ja karistuse vahelise põhjusliku seose tajumine, mis tingib ka vastavad süü- ja hirmuaistinguid. Näiteks järgmises intervjuulõigus ilmneb klassikaline süü ja karistuse motiivistik - lapsed peavad vaimolendi ilmumist tema rahulolematuse märgiks, hakates seejärel otsima võimalusi tema rahulolematuse põhjuste teadasaamiseks, et need kõrvaldada:

Poiss 9 a: Vanas majas kummitab. Eile lubas isa meil seda uurima minna. Me hakkasime sealt majast juba ära minema, kustutasime tule ära, kui tuli läks iseenesest korraks uuesti põlema ja siis kustus ka iseenesest vähehaaval. Ja siis me ehmusime ja läksime välja ja tõmbasime ukse kinni ja siis kuulsime kahte sellist valju sammu majas nagu tümp-tümp. Tahtsime ukse lukku panna ja keegi nagu oleks tõmmanud võtit sissepoole. Ja siis me vaatasime aknast sisse ja seal oli inimkogu. Arvasin algul, et see on minu vari, aga see kogu liikus lihtsalt minema.

Intervjueerija: Mis te arvate, mis see siis oli?

Poiss (9 a): Kummitus. Jaan. See vanaperemees.

Intervjueerija: Miks ta siis ilmub?

Poiss (13 a): Pole rahul millegagi, noh. Sellepärast tuleb.

Intervjueerija: Mida siis ette võtta saaks?

Poiss (13 a): Peaks temalt uurima, mida ta tahab.

Intervjueerija: Kuidas seda teha saab?

Poiss (13 a): Peaks temalt küsima.

Poiss (9 a): A me ei julge.

Intervjueerija: Aga mis te arvate, millega ta rahul pole?

Poiss (13 a): Võib-olla sellega, et me majast raha võtsime.

Antud juhul lahendas laste jaoks olukorra see, kui täiskasvanud rääkisid neile traditsioonilisi muistendeid, milles vaimolendite aktiivsuse tingisid positiivsemad põhjused. Seega langes laste silmis ära ühene seos süü ja karistusega ning vaimu kohalolu tajumine ei seostunud enam hirmu, vaid majavaimu funktsioonist lähtuva kaitsega.

Lapseea üleloomulikud kogemused jätavad sageli kustumatu jälje ja kantakse mälus kaasa täiskasvanuikka. Koolipärimuse puhul on retrospektiivis jutustamise iseloomulikke jooni võimalik jälgida vaid piiratult, kuna ajaline distants kogetu ja rääkimise vahel oli lühike, kuid mõningate täiskasvanute jutustatud lapseea kogemuste põhjal torkab silma põhjalik, nüansirikas sõnastus - osalt ehk seetõttu, et vanemal inimesel on üldse rohkem sõnastamisoskust ja elukogemust, osalt aga jutusüžee kristalliseerumise tõttu aja jooksul. Näiteks on järgmine kirjeldus kohtumisest tulnukalaadsete olenditega filmilikult 
detailne, ka emotsionaalsete reaktsioonide kirjeldus on väga ehe (nutt, südame pekslemine, paanika):

Ja vaimude kohta ütlen niipalju, et olen ka neid näinud. [---] olin 7 aastane laps kui ma oma vanematega ühes talumajas elasin. ühel päeval kui liivakastis mängisin, märkasin, et minu poole tuleb üks mees, naerul näoga. tõusin püsti, et kodu poole joosta. äkki ilmus nagu õhust minu ette teine mees. Sattusin paanikasse ja jooksin tagasi liivakasti poole. seal oli juba kolmas mees. Jäin seisma ja nad moodustasid minu ümber ringi. seisin nende keskel, ja hakkasin nutma. nad vahtisid mind vaikides. mina nutsin ja mäletan et mõtlesin et kes te olete, mis te tahate, omal süda pekslemas rinnus. äkki nad läksid minust natuke eemale seisma, ise samal ajal mind vahtides. lõpetasin nutu ja tahtsin kodu poole joosta, kuid ei saanud, sest jalad olid nagu halvatud ja üks nendest meestest lähenes mulle imeliku näoga. hakkasin uuesti nutma ja siis see mees ütles, et tydruk, ära nuta, me ei tee sulle midagi. siis läks ta tagasi meeste juurde ja haihtusid. järgmisel päeval, kui läksin naabrinaisega karjamaale lehmi vaatama, nägime MÕLEMAD kolme meest karjamaal istumas, nende kõrval oli mingi sõiduk. tundsin need mehed ära. naabrinaine ütles neile et miks te võoral karjamaal olete. mehed tõusid vaikides, ja läksid oma sõidukisse, mis vaikselt ära sõitis. Rohi oli sõiduki alt põlenud. Sõiduk ise oli halli värvi ja väike. Naabrinaine oli nii paanikas, ja kutsus mingid tegelinskid kohale. Minu vanemad ei lubanud mul nendele midagi rääkida, öeldes et muidu mind pannakse hullumajja ja sealt ma välja ei saa. oli ju sügav vene aeg siis (http://naistekas.delfi.ee/foorum, naine, 7.11.2009).

\section{Usundilised kaitseviisid}

Õpilaspärimuse materjalis leidus hulgaliselt maagiliste või muude üleloomulikkusel põhinevate kaitseviiside kirjeldusi (selle kohta oli viimase kogumisaktsiooni küsitluskavas ka eraldi küsimus). Võis täheldada, et turvalisuse taasloomise vahendid õpitakse üldjuhul samadest allikatest, kust on pärit hirmud - meediast, kuuldud pärimusest. Sealjuures võisid lapsed kasutada usundilisi kaitsemehhanisme lisaks usundiliste hirmuolendite (näiteks kollid, tulnukad, vampiirid) ka mitte otseselt üleloomulikkusega seotud hirmude pareerimiseks (nt kaitsvate amulettide, buddha- ja kaitseinglikujude või unenäopüüdjate kasutamine halbade unenägude või halva tuju ärahoidmiseks). Sageli olid esindatud pöördumised surnud esivanemate poole või nende kaitsva läheduse tajumine. Väga levinud olid mitmesugused amuletid (eelkõige poolvääriskivid, 
kaitseinglid, tähtkujuamuletid, käepaelad), kirjeldati ka meieisapalve ja loitsude kasutamist ning kaitserituaale (nt ristimärgi või kaitseringi tegemine).

Nii nagu vanemas täiskasvanupärimuses, kus pahatahtlike üleloomulike olendite vastu aitab kavalus ja nutikus, jätkub see tänapäeva õpilaspärimuses, lisandub vältiv käitumine (paljud õpilased enda sõnul ohtlikuks peetud kohtadesse ei lähe ja hoiduvad üleloomulikkusega seotud rituaalides osalemast). Järgnevas tekstis on selgelt näha erinevate olendite kategoriseerimine halbadeks-ohtlikeks ja headeks-kaitsvateks ning loetletud moodused, kuidas end halbade vastu kaitsta.

Tüdruk (7 a): Pahad on kummitused, kollid, ahjualused. Head on kaitseinglid ja haldjad. Appi kutsutakse niiviisi, et palud abi, ning pahade eest tuleb kappi pugeda. Poiss (11 a): Pahad on mutandid, head on kaisumõmmid ja ka kassid. Häid kutsutakse appi nende peale mõeldes ning pahasid saab mõtte jõul kontrollida. Tüdruk (13 a): Pahad on trollid ja sookollid. Head on kaitseinglid ja majavaimud. Häid saab appi kutsuda nende peale mõeldes ning halbu saab tõrjuda, kui mõtled ilusate asjade peale - see ei lase halba ligi (intervjuu ühe pere lastega, Ida-Virumaa, 2016).

Nii nagu vanemates muistendites, on ka nüüdisaja isikukogemuslugudes tihti kirjeldatud mõlemad poolused: nii käitumine, mis viib kontrolli kadumiseni, kui ka teod, millega on võimalik saavutada kontrolli taastumine:

Ühes laagris tahtsid ühed tüdrukud valget daami kutsuda. Nad kastsid ühe kammi vee sisse ja kuivatasid küünlavalgel. Siis tuli valge daam. Ta hakkas neid taga ajama. Nad ei saanud enam teda ära ajada. Kuid siis murdis üks tüdrukutest selle kammi katki ja valge daam kadus. (EKRK I 97, $265<$ Tartu, poiss, 11 a (1992))

Järgnevas intervjuukatkes avaldub kujutluse tasandil kaitsevariantide läbimängimine, milles huumor ja iseenda hirmude naeruvääristamine segunevad tõsimeelse kaitsestrateegiate üle arutamisega:

Poiss (13 a): Meil koolis ka kummitab. Ükskord 2-3 aastat tagasi meil oli kontrolltöö ja äkki läks iseenesest samal ajal aken ja uks lahti. Kõik olid jumala ehmunud. [---]

Intervjueerija: Aga millest seal siis see kummitamine võis olla?

Poiss (13 a): Ma olen kuulnud, et sõja ajal oli seal kooli keldris nagu haigla. Mitte päris haigla, aga selline koht, kuhu toodi haavatud ja raviti neid. Ja mõned siis surid ära ja need kummitavad.

Intervjueerija: Mis siis teha saab, et need kummitused enam ei kummitaks? 
Poiss (13 a): Kool õhku lasta (naerab).

Poiss (9 a, pooltõsiselt): Aga hinged ei sure ju kunagi. Seega kui kool õhku lasta, siis paisatakse need hinged lihtsalt teise kohta, aga nad jäävad alles (intervjuu kahe poisiga, Tartumaa, 2016).

Kuna aga koolis viibitakse enamasti päevasel ajal ja hulgakesi, ei tajuta selliseid kummitusjuhtumeid üldjuhul probleemina, vaid pigem põnevust tekitavana, kuid siiski esineb mõttemänge teemal, mida keegi teeks, kui ta vaimuga kokku satuks.

Vanemas pärimuses peaaegu tundmatud on viimastel aastatel nii täiskasvanute kui laste usundilises pärimuses tugevalt esile tõusnud kaitsefunktsioonilised hinge- ja väeloomad ning üleloomuliku kaitsja rollis lemmikloomad. Mõningates tekstides astusid üleloomuliku kaitsja rollis üles ka kaisuloomad:

Paar aastat tagasi näitas sõbranna mulle ühte klippi ühest õudusfilmist. Mõtlesin, kui õudne see ikka saab olla, ja ootasin kuni ta selle üles leiab. Klippi vaadates tekkisid kõhinad ja juba poole peal ütlesin, et sõbranna selle kinni paneks, sest see polnud lihtsalt hirmus, kuid ka väga rõve vaatepilt. Hiljem kodus oli magama minna küll õudne. Pimedas toas laua kõrval olev tool meenutas olevuse kuju, laua ja kamina taga oli samuti pime nurk, kust olevus oleks välja võinud tulla, ning otsustasin teha barrikaadi oma kaisuloomadest ja patjadest. Muidugi ei jäänud ka tekk üle pea tõmbamata. Selline rutiin kestis üle nelja kuu (ID3554, tüdruk, snd 2003, Heimtali, 2018).

\section{Kokkuvõtteks}

Nagu eelnevast analüüsist selgus, avaldub õpilaste üleloomulikes uskumustes ja vastavate kogemuste tõlgendamisel tugev meediamõju - kujutelmad on muutunud heterogeensemaks ning nende kirjeldamisel kasutatavad nimetused ja muu sõnavara (nt Slenderman, eilienid) on meedia- ja kultuurilaenude toel uuenenud. Siiski püsivad ka traditsioonilise üleloomuliku pärimuse narratiivsed väljundid (nt lood mõisa- ja koolikummitustest) ning vastavad eelteadmised mõjutavad õpilasi oma kogemuste sõnastamisel ja tõlgendamisel. Meedia genereerib eelkõige just oma sugestiivse visuaalse iseloomu tõttu uusi hirme, kuid inspireerib ka kaitsemehhanisme, ning õpilased tajuvad end nendega opereerides valdavalt aktiivsete toimetulijatena ning usuvad, et hea võidab kurja.

Olendipärimusel, sellega seotud hirmudel ja toimetulekuviisidel on jätkuvalt oma osa sotsialiseerumise, maailma kirjeldamise ja hirmude läbitöötamise protsessis. On ju põhihirmud ajas püsivad: hirm surma ees, hirm pimeduse 
ees, hirm tundmatu ja teistsuguse ees, hirm ootamatuse ees, lahutushirm. Arvamus, et seoses nutimaailma pealetungiga usundilised kujutelmad kaovad, pole paika pidanud, ning usundilised motiivid ja süžeeliinid mõjutavad ka tänapäeva õpilaste kogemus- ja kirjeldamismaailma. Seega on ka õpilaspärimuse kontekstis asjakohane Kurt Ranke (1967: 6) juba klassikaks saanud väide inimese kui homo narransi kohta ning Alasdair MacIntyre sedastus, et kogemused omandavad tihtipeale lugude vormi juba enne, kui need jõutakse verbaliseerida (MacIntyre 1981: 212).

\section{Kommentaar}

1 Artikli valmimist toetasid uurimisgrant IUT 22-5 ja Eesti-uuringute Tippkeskus.

\section{Käsikirjalised allikad}

EKRK - Tartu Ülikooli eesti kirjanduse ja rahvaluule kateedri kogu

KP 2007 - Koolipärimuse kogumise võistluse materjalid 2007 Eesti Kirjandusmuuseumis RKM, KP - Eesti Kirjandusmuuseumi rahvaluule osakonna rahvaluulekogu (koolipärimus)

\section{Kirjandus}

Haring, Lee \& Breslerman, Mark 1977. The Cropsey Maniac. New York Folklore 3, lk 15-28.

Hiiemäe, Reet 2016a. Folkloor kui mentaalse enesekaitse vahend: usulise pärimuse pragmaatikast. Doktoritöö. Tartu: Tartu Ülikool (https://dspace.ut.ee/ handle/10062/54880 - 26. juuni 2019).

Hiiemäe, Reet 2016b. Nonverbal event as part of belief narrative. Folklore: Electronic Journal of Folklore 65, lk 38-56 (doi: 10.7592/FEJF2016.65.hiiemae).

Hufford, David J. 1989. The Terror That Comes in the Night. An Experience-Centered Study of Supernatural Assault Traditions. Philadelphia: University of Pennsylvania Press.

Hutto, Daniel D. 2008. Folk Psychological Narratives. The Sociocultural Basis of Understanding Reasons. Massachusetts: Massachusetts Institute of Technology.

Garvis, Susanne 2015. Contemporary Early Childhood Education. Garvis, Susanne \& Ødegaard, Elin Eriksen \& Lemon, Narelle (toim). Beyond Observations. Narratives and Young Children. Rotterdam: Sense Publishers, lk 1-16. 
Koski, Kaarina 2016. Discussing the Supernatural in Contemporary Finland: Discourses, Genres, and Forums. Folklore: Electronic Journal of Folklore 65, lk 11-36 (doi: 10.7592/ FEJF2016.65.koski).

Kõiva, Mare 1995. Ja tegi ukse lahti. Isikuelamused lastepärimuses. Kõiva, Mare (toim). Lipitud-lapitud. Tänapäeva folkloorist 1. Tartu: Eesti Keele Instituut, lk 306-324.

Kõiva, Mare 1997. In a Big Black Town There Was a Big Black House. Journal of the Baltic Institute of Folklore 2 (1), lk 113-133 (http://www.folklore.ee/rl/pubte/ee/bif/bif2/ sisu.html - 26. juuni 2019).

Lurie, Mikhail 2009. Soviet children's humorous folklore: the techniques of the comic. Krikmann, Arvo \& Laineste, Liisi (toim). Permitted laughter: Socialist, Post-Socialist and Never-Socialist Humour. Tartu: ELM Scholarly Press, lk 333-368.

MacIntyre, Alasdair 1981. After Virtue. A Study in Moral Theory. Notre Dame: University of Notre Dame Press.

Partridge, Christopher 2005. The Re-Enchantment of the West: Volume 1: Alternative Spiritualities, Sacralization, Popular Culture and Occulture. London, New York: Bloomsbury T\&T Clark.

Pechey, Rachel \& Halligan, Peter 2012. Prevalence and Correlates of Anomalous Experiences in a Large Non-Clinical Sample. Psychology and Psychotherapy: Theory, Research \& Practice 85 (2), lk 150-162 (doi: 10.1111/j.2044-8341.2011.02024.x).

Raahauge, Kirsten Marie 2016. Ghosts, troubles, difficulties, and challenges: narratives about unexplainable phenomena in contemporary Denmark. Folklore: Electronic Journal of Folklore 65, lk 90-110 (doi: 10.7592/FEJF2016.65.raahauge).

Ranke, Kurt 1967. Kategorienprobleme der Volksprosa. Fabula 9 (1-3), lk 4-12 (doi: 10.1515/fabl.1967.9.1-3.4).

Sutton-Smith, Brian 1981. The Folkstories of Children. Philadelphia: University of Pennsylvania Press.

Taimalu, Merle 2010. Koolieelikute hirmudest Eesti taasiseseisvumise järel laste endi pilgu läbi. Kalmre, Eda (toim). Tulnukad ja internetilapsed. Uurimusi laste- ja noortekultuurist. Tänapäeva folkloorist 8. Tartu: EKM Teaduskirjastus, lk 21-48.

Voolaid, Piret 2007. Koolipärimuse kogumisest Noarootsis ja Vormsis 2006. aasta kevadel. Mäetagused 35, lk 156-170 (doi: 10.7592/MT2007.35.kogumine). 


\title{
Summary
}

\section{Spirits, aliens, and Slenderman: Supernatural experiences in today's school lore}

\author{
Reet Hiiemäe \\ Senior Research Fellow \\ Department of Folkloristics, Estonian Literary Museum \\ reet@folklore.ee
}

Keywords: belief creatures, children's folklore, fears, folk belief, modern folklore

The article concentrates on mapping continuities and changes in the contemporary Estonian school lore about experiences with supernatural beings: main characters, fears, and emotions connected with such supernatural beliefs as well as supernatural protective mechanisms are highlighted. One of the central topics of the article is cultural and linguistic loans (e.g. international newcomers like the Slenderman) and their sources (e.g. films, computer games, narrative folklore). I also investigate the interactions of fantasy and real life, believing and non-believing in schoolchildren's memorates. The article is mainly based on materials that have been collected from schoolchildren since 1992, but I also draw parallels with traditional older folklore. 